\title{
Aziz Efendi’nin Risâlesinde Kürt Emîrleri (IV. Murad Dönemi, 1623-1640)
}

Öz: Yavuz Sultan Selim ile başlayan ve Kanunî Sultan Süleyman ile üst seviyelere çıkan Osmanlı Devleti ile Kürt emîrleri arasındaki ilişkiler, yüzyıl sonra, Kürt emirlerinin neredeyse bütün sosyo-ekonomik ve sosyo-politik güçlerini kaybettikleri bir noktaya evrilmiştir. Kayd-ı hayat şartıyla kendilerine tevcîh edilen Yurtluk-Ocaklık ve Hükümet sancaklarındaki yönetim hakları, bölge valileri tarafından ellerinden alınmıştır. Emîrler, sahip olduklarını kaybetmemek için ribahorlardan (tefecilerden) faizle borç almışlar ve adeta onlara mahkum hale gelmişlerdir Doğu ve Batı seferlerinde önemli bir askerî güç olarak yer alan Kürt emîrlerinin Devlete sadık kalabilmeleri ve bilhassa, İran seferlerinde icrâ ettikleri hayatî desteklerinin devamı için bir takım tedbirlerin alınması gerekiyordu. Azîz Efendi tarafından hazırlanan ve XVII. yüzyılın ikinci çeyreğinde (1632) devletin askerî, idarî ve malî yapısına yönelik tespit, tahlil ve önerilerin yer aldığı risâlede, Kürt emîrlerin sorunları ve bu sorunların çözümüne yönelik sunulan öneriler, iki taraf arasındaki ilişkilerin tamirini ve bu ilişkilerin tamamen kopuşunu engellemeyi amaçlamıştır. Aksi takdirde, memâlik-i mahrûsenin Doğu sınırları ve Kürt coğrafyası Safevîler'in istilasıyla yüzleşmek zorunda kalacaktır.

Anahtar Kelimeler: IV. Murad, Kürt Emîrleri, Yurtluk-Ocaklık Sancağı, Hükümet Sancağı, Hüsrev Paşa, Aziz Efendi Kanunnâmesi.

\section{Kurdish Emirs in the Report of Aziz Efendi (The Reign of Murad IV, 1623-1640)}

\begin{abstract}
Relationships between the Ottoman State and Kurdish emirates started during the reign of Sultan Selim I and ascended to an unsurpassed level during the reign of Sultan Suleiman the Magnificent. A century later, the Kurdish emirs lost their all social-economic and socio-political powers. Until their death, they are given administrative rights in the sancaks (called yurdluk-ocaklık and hükümet sancaks) were defeated by the regional
\end{abstract}

\footnotetext{
Doç Dr., Mardin Artuklu Üniversitesi Tarih Bölümü, feridunb@gmail.com Orcid: https://orcid.org/0000-00024636-207X
} 
governors (beylerbeys). In order not to lose what they have, Kusdish emirs have borrowed interest from the moneylender (ribahor) and have been condemned to them. Kurdish emirs who took part as an important military power in the campaigns of the Ottoman State in the East and West and in particular, they provide for the continuation of vital support to the military expeditions against Iran. It was supposed to remedy their situation. One report that had taken determination, analysis and recommendations regarding the military, administrative and financial structure of the state. It was prepared by Aziz Efendi in the second quarter of the XVII. century (1632). The solutions of problems of the Kurdish emirs were to repair the relations between the Ottoman state and the Kurdish emirs and to prevent these relations from breaking. Otherwise, the Eastern borders of the Ottoman Empire and Kurdish region will have to face the invasion of the Safavids.

Keywords: Murad IV, Kurdish Emirs, Yurtluk-Ocaklık Sancaks, Hukumet Sancaks, Hüsrev Pasha, Kanunname (Sultanic laws and regulations) of Aziz Efendi.

\section{Giriș}

IV. Murad, Osmanlı tahtına oturduğunda, Anadolu'nun bir çok noktasında Celâlî isyanları başgöstermiş, devletin otoritesi neredeyse ortadan kalkmış bulunmaktaydı. Erzurum valisi Abaza Mehmed Paşa'nın başlattığı isyan, Sivas ve Ankara'yı tehdîd edecek güce ulaşmıştı. Yine, Maraş beylerbeyi Kalavun Yusuf Paşa'nın ve Trablusşam valisi Seyfoğlu Yusuf Paşa'nın isyankâr tutumları, İstanbul'un Anadolu'daki gücüne ciddî darbe vurmuştu. Bu sırada (1623), Bağdat valisi Yusuf Paşa'nın, Bağdat eşrâflarından biri olan Bekir Subaşı tarafından darbe ile indirilmesi, İran sınırındaki Osmanlı topraklarını, Safevîler'in istilasına karşı savunmasız bıraktı.

XVI. asrın sonlarına kadar, Osmanlı ordusunun mükemmel yaya kuvveti olan yeniçeriler, bu tarihten sonra, gelişi güzel hammal ve esnaftan olan kimselerin rüşvet karşılığında ocağa alınmasıyla ciddi anlamda zarar gördü (Uzunçarşılı, 2011: III-II, 277). Sipahi ocağındaki askerlerin hem İstanbul'da hem de Anadolu'da devlete ve millete karşı işledikleri suçlar tahammül sınırlarını aştı. Tımarlı sipahilere verilmesi gereken dirliklerin başkalarına verilmesi nedeniyle tımar sisteminde de bozulmalar oldu ve Rumeli'de 40 bin silahlı süvari çıkaran tımarlı sipahilerin sayısı 7-8 bine kadar indi (Uzunçarşılı, 2011: III-II, 283). Askerî sistemdeki bozulmalar ve askerin başına buyruk davranışları o hale geldi ki kapıkulu ocakları tarafından Sadrazam Hafız Ahmed Paşa, IV. Murad'ın gözleri önünde onyedi yerinden bıçaklanarak öldürüldü. Bu olay esnasında isyancılar padişahın tahttan indirilmesi için de girişimde bulundular fakat, başarılı olamadılar. Dönemin tanıklarından birinin anlatılarına göre, Kapıkulu ve sipahiler için başkent İstanbul'da Müslümanların ırzına tecavüz etmek, köşelerde açıkça zina etmek, evleri ve sarayları basıp yağmalamak, kahvehanelerde ve meyhanelerde gayrı meşru fiillerde bulunmak sıradan hale gelmişti (Mehmed Halife, t.y.: 28-29) 
XVII. asrın başlarından itibaren Osmanlı idarî sisteminde yozlaşmalar, ülkenin her yerinde kendini göstermiștir. Sancak beyliğinden liyakat gösterenlerin beylerbeyi yapıldığı sistem bozulmuş, bir kısım sadrazamlar vali tayinlerinde, kanunen almaları gereken caizeleri fazla almak için valilikleri adeta açık artırmaya çıkarmıştır. Bu nedenle, aynı vilâyete bir yıl içinde 5-6 valinin tayin edildiği vakidir. Valiler, büyük rüşvetle makamlarını elde ettikleri için, sadrazamlara ödedikleri paraların katbe kat fazlasını halktan çıkarıp adeta halkı soymuşlardır. Vezir, beylerbeyi, sancak beyi ve saray kadınlarına ait paşmaklık hasları ve vakıf yerlerinin iltizam suretiyle toplanması, Anadolu'da köylünün çift ve çubuğunu terk etmesiyle (çift bozan) sonuçlanmıştır (Uzunçarşılı, 2011: III-II, 292-293).

IV. Murad'ın tahta culusü sırasında devam eden İran seferlerinin ve Anadolu'da devam etmekte olan asayişsizlikler sebebiyle devletin hazinesi neredeyse boşalmış haldeydi. Culüs bahşişinin ödenmesi için saraydaki eski gümüş ve altın eşyadan para kesilmek suretiyle bir takım ihtiyaçlar karşılanma yoluna gidilmişti.

Osmanlı Devleti'nin Doğu ve Güneydoğu'sundaki serhâd bölgesinde bulunan Kürt coğrafyası ${ }^{2}$, Çaldıran Savaşı (1514) sonrasında, Sultan Selim'in çok istekli olmamasına rağmen, Kürtler'in ısrarı üzerine (Özcoşar, 2017: 13) İdrîs-i Bidlîsi'yi,

“... Kürdistan memleketinin melik ve hâkimlerinin kalplerini kazanma ve onların yüce makamlı eșiğe olan kullağa ve hizmetkârlığa dair ahîd ve imanlarını teşvîk etmek ve muhâliflerin muhâlefetine karşı koymak ..."

(Bidlisî, 2001: 237) amacıyla, Urmî ve Uşnî’den Amid (Diyarbakır) ve Malatya'ya kadar olan bölgeleri yöneten Kürt emîrlerine göndermesinden sonra Osmanlı hâkimiyetine girmiştir (Hoca Saadettin, 1862: II, 300; Bidlisî, 2001: 237; Çelebi, 2009: 266-267; Göyünç, 1991: 16).

XVI. asrın ikinci çeyreğinde Kürt coğrafyasında uygulamaya konulan idarî ve malî sistem, Osmanlı Devleti ile Kürt emîrleri arasındaki ilişkilerin uzun süre ve genellikle de sorunsuz bir şekilde devam etmesini sağlamıştı. Fakat, yukarıda da ifade edildiği üzere, XVII. asrın başlarından itibaren Osmanlı Devleti'nin idarî, askerî ve malî yapısında meydana gelen yozlaşmalar (Yeniçeri Ocağı'nın bozulması, tımâr ve zeâmet sisteminin altüst olması, devlet adamlarının alenî bir şekilde rüşvet almaları ve memûriyetlerin rüşvetle satılması vb...) Kürt coğrafyasındaki sosyo-ekonomik ve idarî yapıyı da sarsmıştır. ${ }^{3}$

Çalışmamızda bahsi geçen Kürt Coğrafyası için, Şemseddin Sami'nin Kâmus-ı Türkî isimli eserindeki tanımlama esas alınmıştır. Eserde Kürt coğrafyası,: “Memâlik-i Osmâniyede, hudûd-ı İrâniyenin iki cihetinden ve Cezîre'nin şark ve şimâl taraflarından ibarettir." şeklinde tanımlanmaktadır, bk. Sami, 1317: 1157.

3 Dönemin önemli tanıklarından birinin raporuna: “... Osmanlı saltanatının şevket ve kudreti asker ile, askerin ayakta kalması hazine iledir. Hazinenin geliri reâya iledir. Reâyanın ayakta durması adâlet iledir. Şimdi âlem harap, reâya perişan, hazine noksan üzere... kılıç erbabı bu halde..." şeklinde yansımıştır, bk. Koçibey Bey, 1993: 11. 
Bu çalıșmaya konu olan ve IV. Murad döneminin bürokratlarından biri olan Azîz Efendi tarafından 1632'lerde kaleme alınan Kânûn-nâme-i Sultâni li- Azîz Efendi ${ }^{*}$ isimli risâlede, XVII. asrın ikinci çeyreğinde Osmanlı Devleti'nin idarî, siyâsî ve malî vaziyetini anlamak açısından önemli konulara yer verilmektedir. Risâlenin dördüncü kısmında ise Kürt emîrleri ve coğrafyasıyla ilgili tespit ve öneriler yer almaktadır. Bu çalışmada, risâledeki veriler merkeze alınarak IV. Murad dönemi Osmanlı-Kürt emîrleri arasındaki ilişkiler analiz edilecektir. Risâlenin hazırlanmasından yaklaşık 100 yıl önce başlamış olan güven esasına dayalı bu ilișkilerin, bir asır sonra, neden otorite ve güvensizlik denklemine evrildiği; ortaya konulmaya çalışılacaktır. Ayrıca aynı dönemde hazırlanmış olmasına rağmen Koçi Bey risâlesinde Kürt emîrlerine dair malumata yer verilmemiştir. Aziz Efendi'nin risâlesinde bu bilgilere yer vermesinin, Kürt emîrlerine olan ihtiyacın artması ve onları Safevîler'e kaptırma endişesinden mi kaynaklandığı yoksa Osmanlı idarî sistemindeki yozlaşmanın tamiriyle ilgili rutin düzenlemelerle ilgili mi olduğu değerlendirilecektir.

\section{Kanûnnâmede Kürt Emîrleri}

\section{1 İdarî Durumları}

Osmanlı-Kürt ilişkilerinin seyri, Osmanlı yöneticilerinin Kürt emîrlerine yönelik muamelelerine ve Kürt emîrlerinin Safevîler ile yakınlaşma ve uzaklaşmalarına göre farklılık arzetmiştir. Azîz Efendi'nin risâlesinden hareketle bu ilişkilerin dönemsel olarak itaat, isyan ve tarafsızlık ekseninde vukû bulduğunu söylemek mümkündür. Bu üç eksen üzerinde yapılacak değerlendirmelerin merkezinde Osmanlı Devleti’nin Kürt coğrafyasındaki idarî yapılanmasının mahiyeti ve bu yapılanmanın coğrafyadaki uygulanmasının yer aldığını belirtmek gerekmektedir.

Kürt coğrafyasında, Osmanlı Devleti'nin klasik idarî taksimatı olan beylerbeyilik (eyâlet, vilâyet), sancak (livâ), nahiye, karye (köy) ve mezra'anın (Kunt, 1978: 15-20; Kılıç, 1999: X, 119) dışında hükümet, yurtluk ve ocaklık ile mir-i aşiret yönetim tarzları da benimsenmiştir (Özcoşar, 2018: 3). Serhâd bölgelerindeki yöneticilerin devlete olan bağlılıklarını pekiştirmek maksadıyla oluşturulan Yurtluk-Ocaklık ${ }^{*}$ (Ekrâd) ve Hükümet Sancakları * Kürt coğrafyasında

\footnotetext{
Azîz Efendi"nin “Kânûn-nâme-i Sultânî Li-Azîz Efendi” adlı risalesi, bugün bilindiği kadarıyla tek nüsha olarak Berlin Staatsbibliothek, Preussischer Kulturbesitz, Orientabteilung (Berlin Devlet Kütüphanesi Doğu Bölümü), Nr. 227, Ms. or. quart 1209, Teil 11 (bölüm 11)'de kayıtlıdır. Risale; Ahmed bin Mahmûd tarafından kaleme alınan bir mecmuanın içinde varak, 127 a, ile 129 a-136 b arasında yer almaktadır. Her varak iki parça halinde ve her parça 29 satırdan oluşmaktadır, bk. Çolak, 2010: 102; Çalışmanın geri kalan kısmında bu risâleden, kısaca, Kanûnnâme olarak bahsedilecektir.

* Herhangi bir yerin geliri bir şahsın ömür boyu alması için tahsis edilirse, buna Yurdluk denilirdi. Bu hak babadan oğula geçerse Ocaklık, veya Yurdluk ve Ocaklık diye anılırdı, bk. Sofyalı Ali Çavuş Kanunnâmesi, 1992: 15, 57-58; yurtluk-Ocaklık ve Hükümet sancaklarının statüleri için bk. Kılıç, 1999: 119-137.

* Fetih esnasında karşı gelmeyip, hizmetleri ve itaatleri karşılığında aşiret başlarında bulunan kimselere verilen topraklar onların malı sayılmıştır, 1653 tarihli Sofyalı Ali Çavuş Kanunnâmesi'nde mevcut olan hükümetler şunlardır: Hükûmet-i Cizre (El-Cezire), Hükûmet-i Eğil (Eğin), Hükûmet-i Genç, Hükûmet-i Palu, Hükûmet-i Darru
} 
yaygın olarak oluşturulmuştur. Bu iki sancak sisteminin esas dayanakları, bölgenin Osmanlı hâkimiyetine geçişi sırasında İdris-i Bidlisî̀nin yürüttüğü diplomasi trafiğinde belirlenmiş olan kurallar ve nişan-ı şerifler üzerinden sağlanan anlaşmalarla belirlenmişti (Özcoşar, 2017: 21)

Yurtluk-Ocaklık sancakları hizmetlerinden ötürü, sancak mülkiyeti sancak beyinin ailesine bırakılmış, tımâr ve zeâmetin bulunduğu ve tahrîrin yapıldığı sancaklardı (Aynî Ali Efendi, 1280: 29; Mustafa Nuri Paşa, 1992: 137). Özerk yapılarına rağmen Yurtluk-Ocaklık sancaklarının yöneticileri, sefer esnasında Osmanlı ordusunda yeralmak zorundaydı; mazaretsiz olarak katılmadıkları durumda bu emîrlerin sancakları ellerinden alınarak yine aynı aileden birine tevcîh ediliyordu. Sancak idaresinin aile tekelinde olması bu sancakların en önemli ayrıcalıklarıydı (Kılıç, 2002: IX, 24).

Hükümet sancakları ise mülkiyeti sancak beyinin ailesine bırakılmış, tahrîrin yapılmadığı -dolayısıyla da tımâr ve zeâmetin olmadığı- sancaklardı (Aynî Ali Efendi, 1280: 30). Hâkim olarak isimlendirilen bu sancakların yöneticileri, yargı hariç (merkezden atanan kadılar yargı işlerini yürütüyordu) diğer bütün idarî konularda tasarruf sahibiydiler. Vergileri kendi adına toplayan sancak beyi, yılda bir kez belirli bir miktarını merkez hazineye ödemekteydi (Doğan: 2011: 35). Kayd-ı hayat şartıyla görevlerini yapan hâkimlerin en önemli vazifeleri ahalinin korunmasıydı. Aksi takdirde, sancak beyini azl edip yerine aynı aileden biri atanıyordu. Hükümetlerin sayısı çeşitli dönemlere göre farklı sayıda olmuştur. 1653'te yazılan Sofyalı Ali Çavuş Kanunnâmesi'nde bu sayı dokuz olarak verilmiştir (Sofyalı Ali Çavuş Kanunnâmesi, 1992: 19; Dinç, 2010: 516).

XVII. ilk yarısında, Koçi Bey gibi, Azîz Efendi de devletin içerisinde bulunduğu zorlukların farkındaydı. Bu sebeple sorumlu bir devlet adamı olarak sorunların tespiti ve çözümüne dair bir risâle hazırlama gereği duymuş ve hazırladığı risâleyi IV. Murad'a takdim etmiştir. IV. Murad'ın Azîz Efendi'nin risâlesindeki tespit ve önerileri ne kadar dikkate aldığına dair ulaşabildiğimiz dönemin kaynakları, bizi aydınlatmamaktadır. Fakat özellikle padişahlığının son 78 yılında, bir çok askerî ve idarî yöneticiyi idam etmesi, Celâli isyanlarına sert bir şekilde müdahalesi, Kürt coğrafyasında vuku bulan bazı suistimallere müdahale etmesi devletin ıslahına yönelik hazırlanmış olan raporlardan etkilenmiş olabileceğini akla getirmektedir. Nitekim Cizre Hâkimi Mehmed Bey; Cidalcan, Demirkapı ve Taşkesen isimli köylerin elinden alınıp Sincar sancağına bağlanmasını şikâyete konu edince, IV. Murad bu köylerin tekrar Cizre hâkimine verilmesini Diyarbekir beylerbeyisinden istemiştir (BOA, MD. 86, HK. 14 (26 Muharrem 1046/30 Haziran 1636).

Azîz Efendi'nin Kanûnnâme'nin dördüncü kısmında Kürt bölgelerindeki ictimaî, iktisadî ve siyasî problemlere ışık tutması ve bu problemlere tarafsız bir

(Harru), Hükûmet-i Ekrâd, Hükûmet-i Mihrivânâ, Hükûmet-i Uştî, Hükûmet-i İmâdiye, bk. Sofyalı Ali Çavuş Kanunnâmesi, 1992: 19-20. 
şekilde çözüm önerileri getirmesi, Osmanlı merkez bürokrasinin Kürt coğrafyasını ne kadar önemsediğini göstermiştir. Bu dönemde Kürt emîrlerinin problemleri, Osmanlı merkez idarî sistemindeki yozlaşmaya bağlı olarak çoğalmıştır. Bilhassa devlet merkezinin zayıflaması, valilerin bağımsız iktidar alanı yaratmalarına neden olurken Kürt emîrlerinin hakimiyet alanlarını ise ciddî anlamda daraltmıştır. Bu durum, çoğu zaman kendilerini padişahın temsilcisi olarak gören ve kendilerine özel bir anlam yükleyen valiler ile kendilerini bölgenin asıl sahibi olarak gören Kürt emîrleri arasındaki ilişkileri olumsuz etkilemiştir (Özcoşar, 2017: 33).

Yavuz ve Kanunî’nin Kürt emîrlerine verdikleri ahidnâmeler çerçevesinde, Kürt emîrlerinin yönetimindeki yerlerde azl ve nasb kabul edilmezken bu topraklar, bölge valileri tarafından "ihtimal dahilinde bile olmayan" yabancılara verilmiştir. Kürt emîrlerinin yönetim hakları 40-50-60 bin kuruş gibi değişen rakamlarla başkalarına satılmıştır. İdarî statülerini kaybetmek istemeyen Kürt emîrleri ise valilerin talep ettikleri paraları, faizle borçlanarak ${ }^{4}$ karşılama cihetine gitmişlerdir. Fakat, bu durum bir süre sonra emîrlerinin hem fakirleşmelerine, hem de daha önceleri 60 bin Kürt dilâveriyle Osmanlı saflarında savaşlara katılırlarken, Hemedân ve Dergezin seferlerinde (1630-1631) olduğu gibi, 600-700 asker dahi çıkaramamaları sonucunu ortaya çıkarmıştır (Murphey, 1985: 36). Valiler tarafından Kürt emîrlerinin topraklarına haksızca el konulması ve bir kısmının sebepsiz öldürülmesi, öldürülme korkusu olan emîrlerin topraklarını terk etmeleriyle sonuçlanmıştır (Murphey, 1985: 36).

\subsection{Askerî ve Malî Durumları}

Kanûnnâmede: “Taife-i celîletü'l-menâf (en yüksek zirvedeki halk)” şeklinde tavsîf edilen Kürtler'in, sünnî ve Müslüman oldukları ve katıldıkları birçok savaşta, fetihlerin gerçekleşmesinde önemli rol aldıkları ve Osmanlı Devleti'ne olan bağlııkları bir çok hadisede ıspatlanmış bir halk olarak belirtilmiştir. Osmanlı Devleti'ne olan bağlılıkları sebebiyle Yavuz Sultan Selim ve Kanunî tarafından Kürt coğrafyasındaki Osmanlı yöneticilerine gönderilen ahîdnâme-i hümâyûnlarda Kürtler'in rencide edilmemeleri istenmiştir. Mesela Kanunî, Tebriz ve Azerbaycan seferleri esnasında gösterdikleri yakınlık ve gayretleri sebebiyle Kürt beylerini "şir-i jiyan" ve "bebr-i bayan" olarak tavsif ettikten sonra:

"Hak süphanehu ve teâla sedd-i Yecüc binâ etmeyi i̇skender-i Zülkarneyne müyesser etdiği gibi memâliki mahrûsemden fitne-i yecüci Acem define Kürdistanı bir seddi sedîd ve hisârı hadîd eylemiştir. Allah'a bin şükürler olsun. Ümiddir ki evlâdımı gaflet ve ihmal ile ümereâi Ekrâdın tabiiyetlerini elden kaçırmayalar ve onlara iltifat etmekten geri durmayalar"

sözleriyle Kürtler'in memâlik-i mahrûsenin muhâfızları olduklarının altını çizmiştir (Murphey, 1985: 33-36).

\footnotetext{
${ }^{4}$ Osmanlı devletinde faizin sosyo-ekonomik hayat üzerindeki olumsuz etkisi için bk. Akdağ, 2009: 59-62
} 
Osmanlı askerî varlığı içerisinde etkin bir gücü temsil eden Kürt emîrleri, Osmanlı'nın sadece, Doğu seferlerinde değil aynı zamanda Balkanlar'daki ve Akdeniz'deki ${ }^{*}$ askerî seferlerinde de önemli vazifeler icrâ etmiştir. Kanûnnâmede bu husus ele alınarak, Osmanlı padişahlarına tabî olmayı vacip veya farz-ı ayn olarak gören Kürt emîrlerinin, düzenlenen askerî seferlere 50-60 bin askerle katıldıkları belirtilmiştir. Kürt emîrlerinin, Sultan III. Murad zamanında (1574-1595) yapılan İran seferlerine mâiyetleriyle katılmaları sayesinde Rumeli beylerbeyi ve yeniçeri ağasının seferlere katılmasına gerek duyulmamıştır. Sadece vezirlerden birisinin Rumeli'den 4-5 sancak beyi ve yeniçeri kethüdasının 3-4 bin yeniçeri ile katıldığı seferler, Kürt askerlerinin katılımıyla birlikte kısa zamanda önemli başarılar getirmiştir (Murphey, 1985: 35). Kürt emîrlerinin Osmanlı askerî varlığı içerisinde önemli görevler icra etmelerinin kendileri açısından önemli kazançları vardı. Öncelikle yurtluk-ocaklık ile hükümet sancaklarındaki yönetim hakları korunuyordu. Ayrıca yaşadıkları coğrafya Şii Safevîler'in saldırılarına karşı emniyete alınmış oluyordu.

Aziz Efendi, risâlesinde Kürt emîrlerinin IV. Murad döneminde düzenlenen askerî seferlerdeki varlığı ile ilgili örneklere yer vermemiştir. Halbuki bu dönemde İran'a karşı düzenlenen seferlerde ordunun asker ve lojistik ihtiyaçlarını karşılamış, kendi bölgelerinde asayişi sağlamışlardır (Özcoşar, 2017: 23-24).

\subsection{Osmanlı-Safevî Mücadelesinde Kürt Emirleri}

Osmanlı padişahları içerisinde en fazla kan döken padişah olarak ismi geçen IV. Murad ${ }^{5}$, Osmanlı tahtına oturduğunda devlet; sosyo-ekonomik, askerî ve idarî problemlerle çalkalanıyordu. İstanbul'da yeniçeri ve sipâhilerin, Anadolu ise Celâlîlerin isyanları kamu düzenini bozmuştu. Daha önce ifade edildiği gibi devlet merkezinin zayıflaması, taşra bölgelerinde devlet otoritesinin kaybolmasına yol açıyordu. Nitekim Bağdat valisinin bir darbe sonucu yönetimden uzaklaştırılması, bu önemli eyâletin Safevîler'in eline geçmesiyle sonuçlanmıştı.

Bağdat eyâletinde, halk üzerinde etkisi ve otoritesi olan eşrâftan Bekir Subaşı ismindeki komutan, Bağdat Valisi Yusuf Paşa'yı güç kullanarak yerinden edip, şehrin yönetimini ele geçirdi (Hammer, 1994: IX, 16-18). Bu gelişme üzerine, Diyarbekir Beylerbeyisi Hafız Paşa, isyanı bastırmakla görevlendirildi. Bu seferde Hafız destek veren Kürt emîrleri arasında Hazo Beyi Şeref Hân, Eğil Beyi Mümin Hân, Tercil Beyi İbrahim Bey, Palu Beyi Hasan Bey, Erganî Beyi Başıbüyükzâde Ali Bey, Harput Beyi ỉbrahim Bey, İmadiye Beyi Seyyid Hân ve bu sefer esnasında çıkan çatışmada hayatını kaybeden Soran Hâkimi Mustafa Bey de vardı (Naima, 2007: II, 519-520; Hammer, 1994: V, 18-20: Yllmazer, 1990: 644).

\footnotetext{
* Girit ve Kıbrıs'a asker gönderdiklerine dair bk. BOA, MD.12, HK. 241, 242.

${ }^{5} 12$ yaşlında tahta çıkan IV. Murad 27 Temmuz 1612'de doğdu ve 28 sene, 4 ay ve 18 gün yaşadı. 16 yıl 11,5 ay saltanat sürdü, bk. Süreyya, 1996, I, 28.
} 
Bağdat'ı kuşatan (1625) Hafız Paşa, Bekir Subașı'nın Bağdat'ı Safevîlere teslim etme tehdidleri (Bu sırada Bekir Subaşı'nın İran Şahı adına sikke bastırmakta olduğu haberi de alınmıştı) (Naima, 2007: II, 524; Hammer, 1994: V, 23) karşısında onu, Bağdad valiliğine atamak zorunda kalmıştır. Iki taraf arasındaki elçilik görevini İmâdiye Hâkimi Seyyid Han yapmıştır. Seyyid Hân, görüşmeler esnasında Bekir Subaşı'yı uyarıp: “Birkaç günlük ömre mağrur olup, bu denlü vebâli nice irtikâb edersin" diyerek nasihat etmiştir. Görüşmede Seyyid Hân, Bekir Subaşı'ya Rakka valiliğini oğluna da Hille sancağını teklif etmiştir. Bu teklife sinirlenen Bekir Subaşı, Seyyid Hân'ın öldürülmesini emredince, defterdâr Ömer Efendi'nin araya girmesiyle, öldürülmekten kurtulmuş ve göz hapsine alınmıştır (Naima, 2007: II, 524-525; Hammer, 1994: V, 23; Küpeli, 2010: 233). Daha sonra da Bekir Subașı'ya atama fermanı Harput Beyi ibrahim Bey ile gönderilmiş ve Bağdat yeniden Osmanlı yönetimine girmiştir (Peçevî, 1283: II, 393).

Safevîler, Bekir Subaşı'nın Osmanlı Devleti'nin bir valisi olarak Bağdat'a atanmasından bir müddet sonra Subaşı'nın oğlu Derviş Mehmed'i elde ederek, onu babasına karşı ihanete teşvik ettiler. Safevîlerin tuzağına düşen Derviş Mehmed Bağdat'ı Safevîlere teslim etti. Bu sırada esir düşen Bekir Subaşı, Safevîler tarafından yakılarak öldürüldü (Peçevî, 1283: II, 393). İ̧̧galden sonra Bağdat'ın yönetimine Hemedan valisi Safi Kuli Han atandı. Safevîlerin Bağdat'ı ele geçirmesiyle birlikte Irak toprakları tümüyle Safevî tehdidi altına girecektir. Nitekim kısa bir süre sonra Karçgay Han komutasındaki Safevî ordusu Mardin civarına kadar askeri akınlarını genişletmiştir (1624) (Naima, 2007: II, 533; Danişmend, 1972: III, 326-328).

\subsubsection{Hüsrev Paşa ve Kürt Emîrleri}

Azîz Efendi, Sadrazam Hüsrev Paşa'nın Kürt emîrlerine yönelik olumsuz politikasının Osmanlı-Kürt ilişkilerine ciddi darbe vurduğunu düşünmektedir. Bu düşüncesini Sadrazamın Bağdat seferi sırasında (1630) Kürt emîrlerinden bir kısmını haksız bir şekilde öldürmesiyle gerekçelendirmektedir. Onu, şiddetle tenkîd ederek: “... ol gayret ve hâmiyet sahibi kavmi ..." ölüm mertebesine çıkarmakla itham etmiş, yaptıklarının “... ölüm üstüne ölüm ...” getirdiğini belirterek ihânetle suçlamıştır (Murphey, 1985: 36).

Kanûnnâmede ihânetle suçlanan ve Naima'nın ifadesiyle: “...mehîb (heybetli) ve hûnî (kanlı) tabî‘at kimse..." olarak zikredilen Sadrazam Hüsrev Paşa, Bağdat seferine memûr edilmiştir (1629) (Naima, 2007: II, 623, 641). Osmanlı ordusu Musul'a ulaştığında çoğu zaman Osmanlı ve İran arasındaki rekâbette tarafsız kaldığı belirtilen ve Kürt emîrlerinin güzidesi olarak tavsîf edilen İmâdiye ${ }^{6}$ Hâkimi Seyyîd Han7, sadrazama olan muhabbetinden dolayı

\footnotetext{
${ }^{6}$ Soylarının Abbasi halifelerine ulaştıklarını iddia eden İmadiye hâkimleri "Abbasoğulları” diye şöhret bulmuşlardı. Önceleri Şemdinan Vilayeti'ne bağlı Taron Kalesi'nde ikamet ederlerken Taron'dan 400 yıl önce gelmiş olan Bahadin ismindeki ataları sebebiyle, Kürt coğrafyasında "Bahadinân” diye tanınmaktaydılar, bk. Şeref Han, 1971: 125.
} 
Osmanlı ordusuna maiyetiyle birlikte katılarak Musul'un muhâfazasında görev almıştır. Ayrıca Soran Hâkimi Mire Bey, Hüsrev Paşa'ya bağlılığını bildirmiş ve sonra da kendisine hıl'at giydirilmiştir. Bağdat taraflarındaki çölde oturan ve Osmanlı ordusunun iaşe ihtiyacının karşılanması amacıyla 30 bin koyun hazırlayan Baclan Kürdleri -Arap ve Kürtlerden oluşmaktaydılar- 40 bin kişilik kuvvetle Osmanlı ordusuna destek vermiş, beylerine hil'atlar verilmiştir (Naima, 2007: III, 651-652). Bu sırada ordunun zahire ihtiyacının bir kısmı da İmâdiye Hâkimi Seyyîd Hân tarafından karşılanmıştır (Yılmazer, 1990: 718).

Osmanı ordusunda görev alan Soran Hâkimi Mîre Bey'e bağlı bazı askerlerin ordudan firâr etmesi, yeniçeriler tarafından Soran hâkiminin ihâneti olarak yorumlanmıştır. Bu sebeple yeniçeriler, Soran bölgesine saldırmış, bir çok kimseyi kılıçtan geçirip halkın küçük ve büyük baş hayvanlarına el koymuştur. Soran Hâkimi Mîre Bey de firar ederek Erdelân Beyi Ahmed Han'a sığınmıştır. Soran bölgesinin yağmalanması sonrasında, bölgenin ileri gelen kişilerinden ve ulemâdan bir grup Hüsrev Paşa'ya müracaat ederek, ecdatlarının Kanunî Sultan Süleyman ile birlikte Şark seferlerinde görev aldıklarını ve kendilerinin de sünnî müslüman olduklarını belirterek: “... Evkât-ı hamseyi edâ ederüz ve şer-i şerîfe muti ve munkaduz, ahkâm-ı şer'iyyeyi icrâ ederüz...." diyerek af talebinde bulunmuştur. Hüsrev Paşa, taleplerini kabul etmiş ve sonrasında ise el konulan mal ve hayvanlarının kendilerine iadesini sağlamıştır (Yılmazer, 1990: 720). Osmanlı ordusu, Soran bölgesine yakın olan Bestâm Bey'in bölgesine de Kızılbaş'la ittihâdı var diye saldırmıştır (Katip Çelebi, 2009: II, 117). Bu saldırılardan sonra orduda et bolluğu oluşmasına rağmen, zahire ihtiyacı gün geçtikçe artmıştır (Katip Çelebi, 2009: II, 117; Naima, 2007: III, 653). Ordunun artan zahire ihtiyacını Osmanlı ordusunun karargahına 6-7 hânzâde ile gelen Ahmed Hân'ın amca oğlu Murad Hân karşılamıştır (Naima, 2007: III, 653; Hammer, 1994: V, 109).

Bağdat seferinin kış mevsimine denk gelmesi (yağan yağmurlar sebebiyle Dicle ve Fırat nehirleri taşmıştı) el-Cezire bölgesinin bir deniz halini almasına sebep olmuştu. Osmanlı ordusu iklim şartları nedeniyle Musul'da 42 gün kalmış, suların çekilmesini beklemişti (Danişmend, 1972: III, 344). İlim şartlarının düzelmesinden sonra Bağdat'a doğru yola çıkan ordu, Zap suyu kenarına geldiğinde nehrin sularının kabarması ve şiddetli akması nedeniyle yavaşlamak zorunda kalmıştır. Hüsrev Paşa'nın isteğiyle bu bölgede bulunan Kürtler, tulumlardan kelekler bağlayıp binbir zahmet ve meşâkkatle Osmanlı ordusunun nehrin karşı tarafına geçmesini sağlamıştır.

Seferin kış mevsiminde icrâ ediliyor olması, her geçen gün ordunun erzâk ve asker ihtiyacını artırmış ve ordunun hareket kabiliyetini olumsuz etkilemiştir. Bu sebeple Hüsrev Paşa, Kürt emîrlerinin de katıldığı bir meclis toplamak zorunda kalmıştır. Toplantıda yapılan değerlendirmede mevcut koşullarda Bağdat'ın

\footnotetext{
7 Naima, Seyyîd Hanı “... Ekrâd beylerinin güzîdesi Seyyîd Han ki...” diye tavsif ederek şafî mezhebinden gönlü açık bir yaşlı olan Seyyid Han'ın Sultan Süleyman'dan beri Kızılbaşa boyun eğmediğini ve fakat, Osmanlı vali ve vezirlerine de yanaşmadığını belirtir, bk. Naima, 2007: III, 652 .
} 
muhasarasının olanaksız olduğu düşüncesi, kabul görmüştür. Toplantıda karara bağlanılan konulardan biri de öncelikle Osmanlı ordusunu arkadan vurma ihtimali olan ve bu sırada Safevîlerin tarafında yer alan Erdelân* ve Soran Hâkimi Ahmed Hân'ın etkisiz hale getirilmesi olmuştur (Yılmazer, 1990: 718-719). Kürt emîrleri ile Ahmed Hân arasında devam eden husumet ve Seyyîd Hân gibi görüşlerine değer verilen birinin de Ahmed Hân üzerine yapılacak seferi uygun görmesi, bu kararın alınmasında etkili olmuştur. Ayrıca, Bağdat yolu üzerinde stratejik bir noktada bulunan Şehrizor bölgesinin ele geçirilmesi, Osmanlı ordusunun Anadolu ile olan bağlantısının kesintisiz şekilde devamını sağlamış olacaktı (Dinç, 2017: 104)

Alınan karar uyarınca Osmanlı ordusu Dicle sahilini takip ederek, Erdelân ve Soran taraflarına yönelmiştir. Hüsrev Paşa'nın bölgelerine geldiğini haber alan Erdelân şeyhleri ile Ahmed Hân ve kardeşi Mümin Hân, sadrazama bağlılıklarını bildirmiştir: “... Sohran Ekrâdları orduya nüzül ni'met ile gelürlerdi...” (Yılmazer, 1990: 719). Mümin Han'ın sünnî olması sebebiyle, daha fazla takdir görmüş, Ahmed Hân ve askerleri onun emrine verilmiştir. ${ }^{8}$ Bu sırada, Osmanlı Devleti'ne bağlılıklarını bildirenler arasında Suruç Hâkimi Timur Hân ile Erdelân vilâyetindeki 39 sancağın yöneticileri olan (Zap suyundan Şehrizor'a kadar olan bölgedekiler) 20 kadar Kürt hânı da vardı (Naima, 2007: III, 653). Şehrizor'daki Zalm Kalesi'nin Kürt beyi olan Şeyh Abdullah Hüsrev Paşa'ya biat etmek zorunda kalmış ve kendi oğlunu rehine olarak ona bırakmıştır.

Şehrizor bölgesine ulașan Hüsrev Paşa, ordugahını, Kürt coğrafyasının en eski merkezi konumunda olan Şehrizor'a kurmuş ve burada, yedi hafta boyunca Gülanber (Şehrizor Kalesi) isimli kalenin tamiratı ile uğraşmıştır (1630). Naima, bu kalenin tamirini, bu sırada, Hüsrev Paşa'ya itaat için gelmiş ve kendilerine istimâletler verilmiş olan Kürdistan beyleri ve hükümet sahibi aşiret ve kabile hâkimlerinin telkin ettiklerini kaydetmiştir (Naima, 2007: III, 652-655; Hammer, 1994: V, 110-111). Topçular Katibi ise, Hüsrev Paşa'nın kalenin tamir edilip edilmemesiyle ilgili olarak yaptığı toplantıya, beylerbeyiler, sancakbeyleri, alaybeyleri, zu'ama ve çavuşların da katıldığını kaydederek, kalenin yapılmasını isteyenlerden birinin de Erdelân ve Soran Emîri Mümin Hân olduğunu belirtir (Yilmazer, 1990: 725-726).

Bu sefer sırasında, Hazzo Hâkimi Mîr Mehmed Hân'ın kendisini diğer Kürt emîrlerinden üstün tutması gerekçesiyle* öldürülmüştür. Şöyle ki, diğer Kürt emîrleri bir tuğ, (aralarında muteber olanlar iki tuğ çekerdi), Osmanlı

\footnotetext{
Diyarbakır ve Cezire'de kurulan Mervâni devletinin kurucusu olan Ahmed b. Mervân torunlarından ve Diyarbekir hükümdarlarının çocuklarından ve soylarından olan Erdelân Kürtlerinin atası Baba Erdelân, Şehrizor’u ele geçirip burada hakimiyet tesis etmiştir, bk. Şeref Han, 1971: 99-100.

${ }^{8}$ Topçular Katibi Tarihi'nde Ahmed Hân'ın maiyetiyle birlikte Hemedan'a kaçtığı ve İran Şahı ile fesâd peşinde koştuğu kaydedilir, bk. Yılmazer, 1990: 721.

* Osmanlı-Safevî sınırında, bir sadakat sağlama yöntemi olarak rehine siyaseti için bk. Dinç, 2017: 100 vd.

* Halıcızâde Hüsrev Paşa'yı: “Bu adam, kendiliğinden vezirlik takınmıștır. Karakola gitmez, hizmet ve birlikte gönlü olmadıkça işlemez, ferman-ı şerifinize itaati istemeyecektir. Sizler bu memleketten gittikten sonra, kimseye baş eğmez ve itaat etmez, başımıza bela olur." diyerek kışkırtmıştır, bk. Naima, 2007: III, 662.
} 
beylerbeyleri de iki tuğ sahibi iken, Mîr Mehmed Hân kendisini vezir mertebesinde görerek üç tuğ çekmişti. Bu tarz davranışları, Halıcızâde'nin sık sık şikâyetine konu olunca Hüsrev Paşa, Mîr Mehmed Hân'ı uyarmış ${ }^{9}$, uyarısı sonuç vermeyince, öldürülmesine karar vermiştir. Topçular Kâtibi'nin anlatımında ise, Bağdat seferi esnasında Osmanlı ordusunda bulunan Mîr Mehmed Hân'ın, sefere katılma konusunda esnek davranması ve orduda bozgunculuk yapması sebebiyle Hüsrev Paşa tarafından uyarılmıştır. Osmanlı ordusundaki bazı iki yüzlü şahsiyetlerin, Halıcızâde Mustafa Paşa'yı, padişahın emrine karşı gelmek, sadrıazamın emirlerine muhalefet etmek ve devlet malına el uzatıp yalan söylemekle suçlamaları, Hazzo Hâkimi'ni de yoldan çıkmak ve Osmanlı ordusunu terk edip ihânet etme potensiyeline sahip olmakla itham etmeleri, Hüsrev Paşa'nın idam kararlarında etkili olmuştur (Yılmazer, 1990: 734). Sebep her ne olursa olsun, öldürüleceğini anlayan Mîr Mehmed Hân, Hüsrev Paşa'nın huzuruna çağrılmıştır. Görüşme esnasında, Hüsrev Paşa'yı hançerle öldürme teşebbüsünde bulunmuştur. Sonuç itibariyle muvaffak olamamış ve muhâfızlar tarafından öldürülmüştür. Daha sonra da mallarına el konulmuştur (Katip Çelebi, 2009: II, 122; Naima, 2007: III, 662-663).

Hüsrev Paşa'nın Kürt bölgelerinde, yeterli gerekçeler olmadan yaptığı askerî operasyonlar ve zaman zaman vukû bulan yağmalama faaliyetleri ile bu faaliyetler esnasında bazı Kürt emîrleri için verdiği idam kararları, hem bölge yöneticilerinde, hem de, bölge halkında ciddî endişeye yol açmıştır (Naima, 2007: III, 652-653). Mîr Mehmed Hân'ın öldürülmesi bu endişeleri daha da arttırmıştır. Hüsrev Paşa, halkı teskîn etmek amacıyla (belki de Kürtlerin Acem tarafına geçebilecekleri endişesiyle) (Katip Çelebi, 2009: II, 122; Naima, 2007: III, 663) Halıcızâde Mustafa Paşa'yı da idam etmiştir. Halıcızâdenin öldürülmesinden sonra Kürtler: "Hanımıza ettiğini buldu" diyerek sevinç gösterisinde bulunmuştur. (Naima, 2007: III, 663; Kıbrısılı Mehmed Kamil Paşa, 1327: II, 58). Görüldüğü üzere, Kürtlerin desteğini kaybetmeyi ve onları Safevîler'e kaptırmayı göze alamayan Osmanlı sadrazamı, kendi valisini feda etmekten imtinâ etmemiştir.

Osmanlı ordusu Bağdat kuşatmasında iken Kürt emîrlerinden Kasım Hân, Lur Hân ve devrik Erdelân Beyi Ahmed Hân'ın desteğindeki (30.000 kişilik askerî kuvvetle) Safevî ordusu, Şehrizor ${ }^{10}$ ve Dertengi üzerine sevk edilmiştir. Şehrizor, Safevîler tarafından tekrar işgali edilince, Hân Ahmed'in kardeşi Mümin Hân, yukarıda ifade edilmişti-Osmanlı Devleti’ne tabî olduğu gerekçesiyle İsfahan'a gönderilip hapse atılmıştır. Şehrizor tarafının yeniden işgal edildiği Hüsrev

\footnotetext{
9 Hüsrev Paşa onu: “Niçin karakola ta'yin olundukta tekâsül edersin. Diyarbekir Emîrü'-ümerâsı Halıcl-zâde'nin bir dahi muhâlefetin mesmû'um olursa seni bilâ-emân katl ederim" diye uyarmıştı, bk. Naima, 2007: III, 662.

${ }^{10}$ Osmanlı Devleti bugün Kuzey Irak sınırları içerisinde yeralan Şehrizor’un muhâfazasına daha önce de önemli miktarda askerî kuvvet göndermiști. Memun bey döneminde Şehrizor’a İran Şah'ı tarafından yapılan saldıının karşılanması maksadıyla, Karaman, Sivas, Halep, Maraş, Diyarbekir ve Bağdat valilerine emirnâmeler gönderilerek gereğinin yapılması istenmiştir, bk. Parmaksızoğlu, 1973: 222.
} 
Paşa'ya bildirilince Bağdat kuşatmasını kaldırıp Musul'a çekilmiştir* . Hüsrev Paşa'nın çekilmesinden sonra serhâd bölgelerinde sıkça görülen taraf değiştirme, güce göre konum belirleme ve kendini koruma ve garantiye alma politikası bir kez daha vuku bulmuştur. Nitekim, Erdelân ve Şehrizor taraflarındaki Kürt emîrleri: "El-Hükmü limen galeb (hüküm galip gelenindir)" diyerek yeniden Safevîler'in tarafına geçip saf değiştirmiştir. (Katip Çelebi, 2009: II, 131; Naima, 2007: III, 680-68; Yılmazer, 1990: 752, 754).

Tarihçi Naima, Kürt emîrlerinin saf değiştirme nedenini bölge merkeziyle açıklamaya çalışır. Ona göre bir bölgenin merkezi ele geçirilmeden veya elde tutulmadan taşra bölgelerinin tabiiyetlerinin herhangi bir anlamı yoktu. Nitekim, bölgenin merkezi olan Bağdat elde tutulamadığı için, daha önce Hüsrev Paşa'ya biat eden 30 kadar Kürt emîri taraf değiștirmiştir. Naima, tarih şuurundan yoksun ve dik başlı olarak gördüğü Hüsrev Paşa'nın ${ }^{11}$ bu gerçeği bilmemesinin kendisine çok zaman kaybettirdiğini de yorumlarına eklemiştir (Katip Çelebi, 2009: II, 130; Naima, 2007: III, 679).

Revan seferinin icrâ edildiği sene (1635), Diyarbekir Beylerbeyisi olan Murtazâ Paşa, Rüstem Hân komutasındaki 60 bin kişilik Safevî ordusunun (Topçular Kâtibi bu sayıyı 70 bin larak verir, bk. Yılmazer, 1990: 771) Van şehrine saldırmak için harekete geçtiği haberini almıştır. Safevî kuvvetlerini durdurmak ve şehri savunmak için yola çıkan Murtazâ Paşa, Van taraflarındaki Sultançayırı semtine ulaşınca Memi Paşaoğlu, Ali Paşa ve bazı Kürt emîrleri kendisini karşılamaya gelmişlerdir. Karşılama heyetindekiler, 60 bin kişilik Kızılbaş ordusuyla savaşmaya güçlerinin olmadığını ifade ettiklerinde Murtazâ Paşa, onları tehdit etmiş şayet kendisine katılmayacak olurlarsa sefer dönüşü bu ihanetin bedelini ödeyeceklerini ifade etmiştir. Bu tehdit üzerine Kürt emîrleri ve diğerleri sefere katılmıştır. Osmanlı ordusu, Başköy isimli mahale geldiğinde ise Kürt ümerâsından Bahaüddin Bey, ikisi sağ ele geçirilmiş onunun da başı kesilmiş oldukları halde 12 Kızılbaşı Murtazâ Paşa'ya teslim etmiştir (Naima, 2007: III, 806). Bu sefere destek verenler arasında Kürt emîrlerinden Bitlis ve Hazzo Hâkimleri de vardı (Yılmazer, 1990: 771).

\footnotetext{
* Ayrıca, Kürtler'in önerisiyle Şehrizor kalesinin tamiri için yaklaşık iki ay gibi uzun bir süre uğraşması ve bölgedeki Arapların tavsiyelerine uyarak Hille ve Cevâzir taraflarına 10 bin kadar kuvvet göndermiş olması başarısızlığının diğer bir nedenleri arasında idi, bk. Naima, 2007: III, 679. Hüsrev Paşa'nın Bağdat'ın seferi, başarısızlıkla sonuçlanmış ve bu başarısızlığın faturası Hüsrev Paşa'ya kesilerek sadrazamlıktan azl edilmiş, daha sonra boğdurularak idam edilmiştir, bk. Katip Çelebi, 2009: II, 140; Peçevî, 1283: II, 419; Naima, 2007: III, 696-697; Hammer, 1994: V, 131-132; Danişmend, 1992: III, 351 ). Bir müddet sonra da Özi muhafazasında bulunan ve daha sonra da Diyarbekir Beylerbeyliğine atanan Murtazâ Paşa tarafından, padişahın fermanı mucibince öldürülmüştür, bk. Naima, 2007: III, 704-707.

${ }^{11}$ Boşnak asıllı olan Hüsrev Paşa, alay ve gösterişi çok seven zalim birisiydi. Kan dökmek tabiatında vardı. Zeki ve muktedir olmasına rağmen ihtirası zeka ve iktidarının önüne geçmişti, bk. Katip çelebi, 2009:, II, 149; Danişmend, 1992:III, 339; Peçevî ise, Hüsrev Paşa'yı: “Vezîr bî nezîr (eşsiz)...” olarak tarif ederek, durmaksızın çalıştığını ve düşmandan öç almakta gösterdiği olağanüstü çabalarının görmezden gelindiğini ve kendisine garez besleyenlerin tahrikleri sonucunda görevden alındığını kaydetmiştir, bk. Peçevî, 1283: II, 419.
} 


\subsubsection{Mihriban Savaşında (1636) Kürt Emîrleri}

Revan kalesinini fethinden (1635) sonra İstanbul'a dönen IV. Murad, Van Beylerbeyisi Dilâver Paşa'dan İran Şahı'nın Tebriz'e geldiği ve Revan üzerine bir sefer düzenlemek için savaş hazırlıkları yaptığına dair bir mektup almıştır (11.12.1635). (Naima, 2007: III, 829). Kısa bir süre sonra da Safevîler, Revân'ı muhasara etmiştir. Üç ay boyunca Osmanlı kuvvetleri tarafından müdafaa edilen kale, 1 Nisan 1636'da tekrar Safevîlerin eline geçmiştir. Müdafaa esnasında Murtazâ Paşa hayatını kaybetmiştir (Naima, 2007: III, 829-831).

Revân'ın Safevîler tarafından işgali sonrasında aynı yıl Şam Beylerbeyi Küçük Ahmed Paşa*, İran üzerine yürümeye karar vermiştir. Bu sırada İran şahının komutanlarından biri olan Rüstem Hân, yaklaşık 20 bin kişilik bir askerî kuvvetle, Güneydeki Şehrizor ve Kerkük taraflarına yönelmiştir (Naima, 2007: III, 834). Musul'da karargah kuran Küçük Ahmed Paşa, daha önce Safevîler tarafında yer alan Erdelân bölgesinin güçlü Kürt beyi Ahmed Hân*ile dostluk ilişkileri kurup ve ittifak yapmıştır. Ahmed Hân'ın Osmanlı tarafıyla dostluk kurmasının sebebi İran Şahı Safi'nin, kendisinden önce ülkeyi yöneten Şah Abbas'ın komutanlarını idam etmesi ve bu arada da Ahmed Hân'ı ortadan kaldırmaya * çalışmasıydı (Katip Çelebi, 2009: II, 185). Osmanlı yönetimi, aralarında kurulan dostluğun göstergesi olarak Ahmed Hân'a bir hi'at ve pırlantalarla bezenmiş bir kılıç göndermiş ve payesinin işareti olarak da iki tuğ ile onurlandırmıştır (BOA, MD.86, HK.84 (18 Rabiülahir 1046/19 Eylül 1636). Ahmed Hân, kendi adına sikke bastırmış ve yönetimi altındaki yerlere valiler atamaya başlamıştır (Penahi, 2017: 87, dn. 26). Daha sonra IV. Murad, hem Küçük Ahmed Paşa'ya hem de Ahmed Hân’a Osmanlı topraklarına doğru genişleme amacında olan Safevîler'i engellemeleri ve Safevîler'in işgal ettikleri yerlerden çıkarılması görevini vermiştir (BOA, MD.86, HK.84 (18 Rabiülahir 1046/19 Eylül 1636). Küçük Ahmed Paşa ve Ahmed Hân’a yardım için bölgedeki Kürt emîrlerine fermânlar gönderilmiştir (bazıları için bk. BOA, MD.86, HK.85-101 (18 Rabiülahir 1046/19 Eylül 1636).

Safevîler hem genişleme stratejilerine bağlı olarak hem de Ahmed Hân'ı cezalandırmak (Penahi, 2017: 87) ve Şehrizor taraflarını tamamen ele geçirmek için Zeynel Hân komutasında bir orduyu bölgeye sevk etmiştir. İran şahına Hindistan'dan gönderilen büyük bir filin de olduğu bu orduyu durdurmak amacıyla Küçük Ahmed Paşa, bir askerî birliği, Safevî ordusunun üzerine sevk etmiştir. İki taraf arasında meydana gelen savaşı Osmanlı tarafı kazanmıştır.

\footnotetext{
* Küçük Ahmed Paşa'nın Osmanlı idarî kademelerinde yaptığı faaliyetler ve atandığı idarî mertebeler için bk. Naima, 2007: III, 836-837.

* Naima, Ahmed Hân'ın Eyyubî Kürtleri sülalesinden Halo Han'ın oğlu olduğunu belirtir, Ahmed Han, sünni olmakla birlikte Şah Abbas'ın kızıyla evlenerek, taraf değiştirmişti, bk. Naima, 2007: III, 837.

* Modern bir çalışmada, Ahmed Han'ın Şah Safi ile mücadeleye başlamasının sebebi olarak, Şah Abbas'ın kızkardeşi Zerrinkulah Hatun'dan olan ve Safevîler sarayında rehin tutulan oğlu Sorhab'ın gözlerine Sah Safi'nin mil çektirmesi olarak gösterilmiştir. Bu olay sonrasında Ahmed Hân bir süre aklî dengesini yitirmiş, sonrasında iyileşmiştir, ayrıntılar için bk, Penahi, 2017: 85-86.
} 
Savaş sonunda ele geçirilen Hind fili de İstanbul'a gönderilmiştir. (Katip Çelebi, 2009: II, 185; Naima, 2007: III, 837).

İran Şahı Safî, mirahoru Zeynel Hân'ın Osmanlı kuvvetleri tarafından yenilgiye uğratılmasından sonra, bu kez, daha büyük bir orduyu (30-40 bin kişilik) Şehrizor bölgesinin işgali için göndermiştir. Safevîlerin gelişini haber alan Küçük Ahmed Paşa komutasındaki Osmanlı kuvvetleri ve Ahmed Hân savaş hazırlıkları yapmaya başlamıştır. Hazırlıklar kapsamında, Hân Ahmed'in yakınları ve ailesi, güvenlikleri amacıyla Musul'a götürülmüştür. ${ }^{12}$ Daha sonra Safevî ordusuyla Mihriban Ovası'ında karşılaşan Osmanlı ordusu ve Kürt güçleri savaşı kaybetmiştir (1636) (Yılmazer, 2006: XXXI, 181). Çatışmalar esnasında Şam Beylerbeyisi Küçük Ahmed Paşa hayatını kaybetmiştir. Daha sonra da Şam eyâleti Mehmed Paşa'ya verilmiştir. ( BOA, MD.86, HK. 104, (22 Rebiülahir 1046/23 Eylül 1636). Bu savaşta, Safevîler tarafında Ekrâd-ı Lur Hân denilen Kürt kabileleri de yer almıştır (Yılmazer, 1990: 819). Ahmed Hân ise hayatta kalmış olan askerleriyle Musul'a kaçmayı başarmış, fakat bir süre sonra da üzüntüsünden dolayı (gayret-i Kürdiyet müktezâsınca) vefat etmiştir (Katip Çelebi, 2009: II, 185; Naima, 2007: III, 837-839; Zinkeisen, 2001: IV, 111-112).

IV. Murad'ın Bağdat seferi esnasında Osmanlı ordusu; Musul taraflarına vardığında (1638) Kürt emîrlerinden Seyyîd Hânzâde, Soran Kürtleri ve Mîre Bey'in bölgesinden Kürtler, Osmanlı ordusundaki topların sevkiyatında görev almıştır. Daha öncesinde Kürt emîrlerinin bir kısmı, IV. Murad'ı Diyarbakır'da karşılamış kendilerine padişah tarafından hıl'atlar verilmişti (Yılmazer, 1990: 849850). Sefer öncesi ve sonrasında, Osmanlı ordusuna destek vermeyen Aştî aşireti Hâkimi Kürd Ali ise Sadrazam Kara Mustafa Paşa'nın emriyle öldürülmüştür. Aynı şekilde, Hakkâri Hâkimi Mîr İmâmüddin, isyan üzere olduğu ve isyan sonrasında çıkma ihtimali olan fitneye mahal vermemek için, Van Valisi Ahmed Paşa öldürülmüştür (Naima, 2007: III, 929).

\section{Kürt Emîrlerinin Sorunlarına Dair Çözüm Önerileri}

Aziz Efendi, Acem fitnesine sedd-i sedîd olan Kürdistan coğrafyasının tamir edilip yeniden ihyâ edilmesini istemiştir. Rakip siyasal otoritelerin çatışma ve alanlarında bulunan ve askerî sınırlar olarak isimlendirilen serhâd* bölgesinde bulunan bu coğrafyanın, Osmanlı tarafında yer alması için Aziz Efendi büyük çaba harcamıştır. Ona göre önceki padişahlar döneminde olduğu gibi, Kürt emîrlerinin Osmanlı Devleti'ne bağlılıkları padişahın muradı olursa ("Fitne-i Ye'cûc-i Acem def ine sedd-i sedîd ve ebvâb-i fesâd-i melâhidenîn bendine âmin kilîd olan vilâyet-i Kürdistânı ta mir ve ihyâ eylemesine ecdâd-ı izamları zamânlarında olduğu gibi vâk i olacak seferlerde asker-i islâmın çarhıcıları elli-altmış bin yarâr nâmdâr Ekrâd-ı

\footnotetext{
${ }^{12}$ Ahmed Hân'ın ailesinin Musul'a getirilmesinden sonra, Erdelân emîliği iki kısma ayrıımıştır. Kerkük veMusul'un yer aldığı Ahmed Hân yönetimindeki yerler Osmanlı Devleti'ne, ỉran tarafında kalan ve Senendec merkezli olan diğer kısmı ise, Erdelan mirlerinden Süleyman Hân'ın (1636-1658) yönetiminde kalmıştır, bk. Renahi, 2017: 87-88.

* Serhâd kavramının Osmanlı-Iran bağlamında değerlendirmesi için bk. Dinç, 2016: 2-4.
} 
Şeca at şi ar olmasına") ilişkilerin tamiri ve Kızılbaşlar'ın eline geçen vilâyetlerin yeniden Osmanlı'nın hâkimiyetine geçmesi için Diyarbekir beylerbeyine, Kürt emîrlerine, Yeniçeri ve Sipahî ocaklarına, Kürt emîrleriyle ilgili fermanların gönderilmesi gerektiğini belirtmiştir (Murphey, 1985: 36).

Kanûnnâmede Kürtlerin: "Kürdistan Beylerinin Diyarbekir, Van ve Musul eyâletlerine tabî olan kimseler olarak..." kaydedilmesi muhtemelen bu üç eyâletin rapora konu edilmesiyle alakalıdır. ${ }^{13} \mathrm{Bu}$ üç eyâletin merkez sancak beyleri, aynı zamanda Paşa Sancakları'nın beyleriydi. Aziz Efendi bu üç eyâlete gönderilmesini istediği emr-i şerîfin muhtevasıyla ilgili olarak şu hususların yer almasını önerir: Öncelikle Kürt ümerâsının ecdâtlarından itibaren Osmanlı Devleti'ne çok sayıda hizmetlerinin olduğu ve sadakatle Osmanlı Devleti'ne bağı oldukları belirtilmelidir. Bugünden sonra (bu hükm-i hümâyûndan sonra) himâye ve korunmaları en kısa sürede sağlanmalıdır. Bundan sonra Kürt hâkimleri vefat ettiklerinde yerlerine oğulları ve akrabaları tayin edilmelidir. Yönetime talip olanlar, asitâneye gelmeleri sağlanmalı ve burada tevcîh işlemleri yapılmalıdır. Bu tarihten sonra, Kürt emîrlerinin değişimine yönelik hiçbir adım atılmamalıdır. Kendilerine devlet güvencesi verilmeli, yeniçeri ve sipâhi taifesinin ve başka şahısların onlara zarar vermelerine müsaade edilmemelidir. Bu ana kadar onlara dair olan muameleler geri alınmalı ve cümlesi borç ızdırabından kurtarılmalıdır ${ }^{14}$.

Kürt emîrlerine ise öncelikle, hıl'atlar ve Osmanlı padişahından istimaletnâmeler ${ }^{*}$ gönderilmelidir. Daha sonra ise, kendilerine gönderilecek hükm-i hümâyûnda ise; Osmanlı Devleti'nin yanında Kızılbaş’a karşı verdikleri mücadelenin ve Diyarbekir'de görevlendirilen kimi yöneticilerin mal ve para kazanmak maksadıyla Kürt emîrlerine haksızlık yaptıklarının padişah tarafından bilindiği, eski durumlarına getirilmelerine yönelik olarak hükümetlerinin yeniden "nesilden nesile" devam edeceği bildirilmelidir. Bilhassa, yapılması gerekenlerle ilgili olarak Diyarbekir beylerbeyine ferman gönderildiğinin altı çizilmelidir. ${ }^{15}$

13 Bu sırada, Diyarbekir eyaleti 19 sancak (11 klasik Osmanlı sancağı, 8 Ekrâd sancağı ve 5 hükümettir, bk. Ali Ayni Efendi: 1280: 29), 1631-1632 tarihlerinde Van Eyâleti'ne bağlı 17 sancağın 13'ü ocaklık olarak tevcih edilmiştir (Kılıç, 2001: 197). Musul eyaleti 6 sancaktan oluşuyordu, bk. Pakalın, 1983: III, 119.

14 "Evvelâ Diyarbekir Beylerbeyisi kullarına müekked ve müședded evâmir-i şerîfleri irsâl buyurulup muhkum tenbîh ve tekid ola ki: Ümer'a-i Ekrâd, devlet-i aliyyenin sadakat ve istikamet ile hayr-hâh-ı olup, ecdâd-ı izamım zaman-ı şerîflerinden ilâ hâzi'l-ân uğur-u humâyûnda envâ-ı hidemât-i mebrûre ve mesâi-i meşkûre-i gayr-ı adîdeleri vücuda gelmiş ve zimmet-i himmet-i mülûkâneme riâyetleri lazım olmağla ba'del-yevm himâyet ve siyânet olmaları aksâ-i murâd-ı humâyûnumdur. Bundan sonra ekrâd hâkimleri fevt olup, yerleri oğullarına ve karındaşlarına verilmek lazıl geldikte, tâlip olanlar âstân-i saadetime gelip, rikâb-ı humâyûnuma yüz sürüp dahi hükümetlerider-i devletimde verilmek fermanım olmuștur. Imdi, min ba'de zinhar ümerâ-i Ekrâd'ın tebdilu tağyirlerine bir vaz'u hareket etmeyip her birine daima ümid u istimâlet ile riayet üzere olduğundan gayrı, Yeniçeri ve Sipahi taifesinden ve sair yerli ve gayrı muamelecilerden bir ferde çiğnetmeyesin. Ve şerî şerîf muktezasınca aldıkları muameleyi geriye red etdirip cümlesini deyn izdırabından halas eyleyesin", bk. (Murphey, 1985:36-37).

* "Soft power" olarak da isimlendirilebilen istimâlet stratejisi, bu coğrafyada Kürt hanedanlarının geleneksel haklarını devam ettirmeleri karşıı̆ı̆ında Osmanlı hakimiyetini tanımaları olarak özetlenebilir bk. Özcoşar, 2017: 18.

15 "Siz sünnî mezhebe mensup kişiler olarak, ceddîm zamanından beri Kızılbaşlara karşı verilen savaşlarda nice silahlı bin adamlarla ordunun önüne düşüp, canla başla mücadele edip, nice güzel fetihlerin gerçekleșmesini sağladınız. Fakat, Diyarbakır'a gönderilen vezirler ve sair beylerbeyilerin kimi mallarınıza el koymak ve kimi de sizi yerlerinizden etmek için size baskı ve zulüm etmiştir. Bu sebeple, kuvvet ve kudretten yoksun düşürüldüğünüz tarafımdan öğrenilmiştir. Sizin ahvalinizle ilgilenmek ve sizi ihyâ ve âbad etmek bizzat bana vacip olmuștur. Evvelâ, herbirinize azîz ecdâdım 
Yeniçeri ve sipâhi taifesine gönderilecek fermânda ise, şu hususların yer alması gerekmektedir; dergah-ı âli kapıcılarından yetkilendirilmiş bir kimse ile ilim ve fazilet sahiplerinden birisi, yeniçeri ve sipâhi ocaklarından adâletli birer kişinin, Kürt emîrlerini tefecilerin zulmünden kurtarmakla görevlendirildikleri bildirilmelidir. Bu tarihten sonra, bu fermânın hilafına olarak Kürt emîrlerinden bir akçe dahi istenmeyecektir. Fermâna göre hareket edilmesi durumunda, Kürt emîrlerinin eski kudret ve kuvvetlerine sahip olacakları, Rumeli, Bosna ve Budin askerlerinin muadili olacakları ve Devlet-i Osmaniye'ye hizmet etmeye devam edecekleri ifade edilmelidir. ${ }^{16}$

Kanûnnâmeden, devlet yönetiminde bulunan bazı kimselerin, mevcut durumdan rahatsız olmadıkları, ıslâh çabası içerisine girenlere de hoş bakmadıkları anlaşılmaktadır. Nitekim, Aziz Efendi," "istidâ i ketm ihfâ-i esrâr" başlıklı son bölümde, IV. Murad'dan raporun gizli tutulmasını isteyerek, bu isteğinin korkudan değil, hayırlara vesile olacakların şerre dönüşmesini istemediğinden olduğunu ifade etmiştir; “ihfâ-yı esrârın fevâ‘idi bisyâr ve ifşâ-yi râzın şe'âmeti bî-şümâr (yapılacakların gizli tutulmasının ne kadar faydası var ise açığa çıkmasının da bir o kadar zararı olduğu)". Ayrıca, "...pîr u emekdâr..." olduğunu ifade ederek, yaşının ilerlemiş olduğunu ve yazdıklarından dolayı herhangi bir endişe duymadığını da eklemiştir (Murphey, 1985: 42).

\section{Sonuç}

Osmanlı ile Safevîler arasındaki tampon bölgede bulunan Kürt coğrafyası, Osmanlı-Safevî savaşlarının sonuçları üzerinde önemli rol oynamıştır. Kürtler'in, büyük oranda, Osmanlı tarafında yer almasından sonra, Osmanlı topraklarına yapılan Safevî saldırılarında, bu coğrafya, bir kalkan görevi görmüştür (seddî hadîd) görmüştür. Ayrıca, bu coğrafyanın jeostratejik konumu, Osmanlı Devleti'nin Azerbaycan, Ortadoğu ve Afrika'yı idaresini (Azerbaycan, Tebriz, Bağdat, Basra, Halep, Şam ve Mısır'ın) kontrolünü kolaylaştırmıştır.

Kürt bölgelerinin, jeostratejik ve teopolitik öneminin farkında olan Osmanlı padişahları Yavuz Sultan Selim ve Kanunî Sultan Süleyman, bu coğrafyanın sosyo-ekonomik ve sosyo-politik şartlarına uygun kısmî özerk

tarafından size verilen ahidnâmeler gereğince, hükümetleri gereği gibi "neslen ba'de neslin" mutasarrıf olmak üzere kendilerine verilecektir. Aranızdan biri Allah'ın emri ile vefât ederse, azl ve nasbınıza beylerbeyiler karışmayıp, boşalan hükümete, ölenin oğlu mu, yoksa kardeși mi olduğu, hükümete dair temessükatı (tapusu senedi) ile asitâne-i saadete gelmelidir ki kendisine hükümet tevcîhi yapılsın. Bu kapsamda, Diyarbakır beylerbeyine muhkem tenbih edilmiştir ki, bundan sonra tebdil ve tağyirinize karışmayacaktır, ve sizi muamelecilerin ve siar zalimliklerinden teaddi ve tecavüzlerinden kurturacaktır, ve daima size göz kulak olup koruyacaktır. Siz bu muamelecilerden ve sair zalimden kurtulduğunuzda günbe gün eski kuvvet ve kudretinize ulaşacaksınız, ve Azîz ecdâdımın zamanında olduğu gibi aşiret ve kabileleriniz ile evvelki hizmetlerden ziyâde hizmetler ve hümâyunum uğurunda nice maslahatlar vücuda getiresiz", bk. Murphy, 1985: 37.

16 "Dergah-ı âli kapıcılarından bir müstakîm mübâşir ile ulemânın ileri gelenlerinden bir akıl sahibi kimse ile Yeniçeri ve sıpâhi ocaklarından birer zabit gidilerek, Kürt emirleri ile faizcilerin ilişkilerini bitirip, daha önce alınmış olan faizi ana sayıp ve aslî maldan aldıkları fazla akçeleri geri vermelerine hükm edip ve her bir Kürt emîrini o zalim borç verenlerin ellerinden kurtarıp zimmetlerini temizlesinler. Ve bundan sonra Kürt emîrlerinden bir kimse borç namılla bir akçe ve bir habbe dahi talep edilmesin şeklinde emri şerîf gönderilsin. Bu fermânın gönderilmesinden sonra borçlardan kurtulan, Kürt emîrleri yeniden kuvvet ve kudretlerine erișerek, Bosna, Rumeli ve Budin eyaletlerinin askerlerine muadil seçkin asker çıkaralar ve devlet-i âliyye ye kavî asker olalar", bk. Murphey, 1985: 38. 
yönetim şekilleri (Ekrâd (yurtluk-ocaklık) ve Hükümet sancakları) oluşturmuştur. Bir ailenin yönetimine bırakılan ve yöneticilerinin kaydı hayat şartıyla yönettiği bu sancaklar, Kürt emîrlerinin Osmanlı Devleti'ne tâbiiyyetini pekiştirmiştir.

Osmanlı Devleti'nin bölgeye yönelik kuşatıcı ve kucaklayıcı politikasına rağmen, Osmanlı-Safevî sınır/cephe bölgesinde yer almaları sebebiyle, Kürt emîrlerinin bir kısmı, politik ve malî kaygılarla, iki devlet arasında denge politikasına yönelmiştir. Hatta bazen, aynı ailenin mensupları arasında farklı politik tercihlerin olduğu vakidir; Kanunî döneminde, Hakkarî Bey’i Zeynel Bey Osmanlı tarafını, kardeşi Bayender Bey ise, Safevîler'in tarafını tutmuştur. Bu çalışmaya konu olan IV. Murad döneminde ise, Erdelân ve Soran Beyi Ahmed Hân'ın Safevîler, İmâdiye Hâkimi Seyyid Hân'ın da Osmanlı'nın yanında yer alması bu denge politikasının bir sonucudur.

Osmanlı Devleti, XVI. asırda siyasî, askerî ve malî alanda en güçlü dönemini yaşamıştır. Bu gücü, güçlü bir yönetim, disiplinli bir ordu ve reâyanın vergileri sağlamıştır. XVI. yüzyılın sonlarından başlayan ve XVII. yy'da giderek artan malî, siyasî ve askerî alanlardaki yozlaşma, memâlik-i mahrûsenin tüm alanlarında kendini hissettirmiştir. Bu yozlaşmanın kendisini iyice hissettirdiği Kürt bölgelerindeki Osmanlı valileri, Kürt emîrlerinden ağır vergiler talep etmiştir. Valilerin malî taleplerini karşılayamayan Kürt emîrlerinin yönetim haklarının ellerinden alınıp başkalarına satılması, Osmanlı Devleti'nin Balkanlar'daki askerî faaliyetlerine zarar verdiği gibi, Safevîler'e karşı yürüttüğü mücadeleye de zarar vermiştir.

İslâm'a ve Osmanlı saltanatına gönülden bağlı olan Kürt emîrlerinin, çoğunlukla teo-politik nedenlerle Osmanlı tarafında yer alması, kendilerine baskı yapan ve haksızca mal varlıklarına el koyan Osmanlı merkez yöneticilerine isyan etmelerine engel teşkil etmemiştir. Kürt coğrafyasında Osmanlı merkez yönetimine karşı oluşabilecek fikri ve duygusal kırılmalar, Osmanlı Devleti'nin Doğu sınırlarını Safevîler'in saldırılarına açık hale getirme potensiyeli taşımıştır. Aynı şekilde, Osmanlı gücü ve gölgesinin Kürt coğrafyasında bulunmadığı zaman bu coğrafyanın sosyo-ekonomik hayatı ve inanç dünyası adeta Safevîlerin istilasına uğramıştır.

\section{Kaynakça}

BOA, MD. 12, HK. 241, 242.

BOA, MD. 86, HK. 14, 84, 85-101, 104.

Akdağ, M. (2009), Türk Halkının Dirlik ve Düzenlik Kavgası "Celâlî İsyanları", İstanbul: Yapı Kredi Yayınları

Ali Aynî Efendi (1280), Kavânin Al-i Osman Der-Hulâsa-i Mezâmin-i Defter-i Dîvân, İstanbul.

Bidlîsî, ì. (2001), Selim Şah-nâme, Hazl.: Hicâbi Kırlangıç, Ankara: Kültür Bakanlığı Yayınları. 
Çelebi, E. (2006), Evliyâ Çelebi Seyahatnâmesi, Haz.: Zekeriya Kurşun, Seyit Ali Kahraman, Yücel Dağlı, İstanbul: Yapı Kredi Yayınları

Çelebi, K. (2009), Fezleketü Akvâli'l-Ahyâr fî ilm't-Târîh ve'l-Ahbâr, Terc.: Seyyid Muhammed es-Seyyid), Ankara: Türk Tarih Kurumu Basımevi.

Çolak, S. (2010), “Aziz Efendi'nin Risalesine Göre 17. Yüzyılda Osmanlı Merkez Ordusunun Durumu”, History Studies, Volume 2/2, s.101-112

Danişmend, ì. H. (1992), İzahlı Osmanlı Tarih Kronolojisi, İstanbul: Türkiye Yayınları.

Dinç, F. (2010), “Osmanlı-iran Ara Coğrafya'sında Din iktidar iliş̧kileri Cizre Hükümeti Örneği (16-19.yy)", Uluslararası Şırnak ve Çevresi Sempozyumu, Şırnak: s.515-527.

Dinç, F. (2017), "Osmanlı-İran Sınır boyunca Sadakat Sağlama Biçimi Olarak Rehine Siyaseti”, Osmanlı Devleti ve Kürtler içerisinde, Edit.: İbrahim Özcoşar ve Shahab Vali, İstanbul: Kitap Yayınevi, 97-135.

Dinç, F. (2016), XIX.Yüzyılda Kerkük (Fizik-idari-Sosyo-Ekonomik Yapı), Yayımlanmamış Doktora Tezi, Fırat Üniversitesi, Sosyal Bilimler Enstitüsü, Elazığ.

Doğan, C. (2011), "XVI. Yüzyıl Osmanlı Idari Yapısı Altında Kürt Emirlikleri ve Statüleri”, SDE Fen Edebiyat Fakültesi Sosyal Bilimler Dergisi, Mayıs, XXIII, 3143.

Göyünç, N. (1991), XVI. Yüzyılda Mardin Sancağı, Ankara: Türk Tarih Kurumu Yayınları.

Hammer, B. J. V. (1994), Büyük Osmanlı Tarihi, Çev.: Mümün Çevik ve Erol Kılıç, İstanbul: Üçdal Neşriyat.

Hoca Saadettin Efendi, (1862), Tacü't-Tevârîh, İstanbul : Tabhane-i Amire.

Kıbrıslı M. K. (1327), Tarih-i Siyasi Devleti Aliye-i Osmaniye, Matbaa-i Ahmed ihsan, İstanbul, II.

Kılıç, O. (2001), Van Eyaleti’ne Bağlı Sancaklar ve Idarî Statüleri (1558-1740), Osmanlı Araştırmaları Dergisi, İstanbul, XXI, 189-210.

Kılıç, O. (1999), "Yurtluk-Ocaklık ve Hükümet Sancaklar Üzerine Bazı Tespitler", OTAM, Ankara, X, 119-137.

Koçi Bey, (1993), Koçi Bey Risâlesi, Sadeleşt.: Zuhuri Danışman, Ankara: MEB Yayınları.

Kunt, i. M. (1978), Sancaktan Eyâlete (1550-1650 Arasında Osmanlı Ümresası ve ì idrares), İstanbul: Boğaziçi Üniversitesi Yayınları.

Küpeli, Ö. (2010), "Irak-ı Arap'ta Osmanlı - Safevî Mücadelesi (XVI-XVII. Yüzyıllar)”, History Studies, Ortadoğu Özel Sayısı, s.227-244.

Mehmet Halife, (t.y.) Tarih-i Ğılmanî, Hazl. ve Sadeleşt.: Ömer Karayumak, Tercüman 1001 Temel Eser: 74.

Mufassal Osmanlı Tarihi (1959), Hazl: Heyet, İstanbul: Tan Matbaası.

Murphey, R. (1985), Kanûn-nâme-i Sultânî li Azîz Efendi, Harvard: Harvard Üniversitesi Basımevi.

Mustafa Nuri Paşa, (1992), Netâicü'l-Vukûat, Kurumları ve Örgütleriyle Osmanlı Tarihi, Sadeleşt.: Neşet Çağatay, Ankara: Türk Tarih Kurumu. 
Naimâ, (2007), Târih-i Na îmâ, Hazl. Mehmet İpşirli, Ankara: Türk Tarih Kurumu.

Özcoşar, í. (2009), Merkezileşme Sürecinde Bir Taşra Kenti Mardin, Mardin: Mardin Artuklu Üniversitesi Yayınları.

Özcoşar, ì. (2018), “Şehir ve İktidar: Tanzimat Öncesi Osmanlı Mardin'inde iktidar", Mukaddime, 2018, 9(1), 1-21

Özcoşar, i. (2017), "Sultan ve Mîr”, Osmanlı Devleti ve Kürtler içerisinde, Edit.: Ibrahim Özcoșar ve Shahab Vali, İstanbul: Kitap Yayınevi, 9-39.

Parmaksızoğlu, ì. (1973), "Kuzey Irak'ta Osmanlı Hâkimiyetinin Kuruluşu ve Memun Bey'in Hatıraları”, Belleten, XXXVII/146, 191-230.

Peçevî, (1283), Tarih-i Peçevî, İstanbul: Marbaai Âmire.

Penahi, K. M., (2017), “Erdelan Kürt Beyliği'nin Osmanlı ve Safevî Devletleri İlişkileri (16 ve 17 Yüzyıllar)", Osmanlı Devleti ve Kürtler içerisinde, (Edit.: Ibrahim Özcoşar ve Shahab Vali, İstanbul: Kitap Yayınevi, 77-97.

Sami, Ş. (1317), Kamus-u Türkî, Dersaadet.

Sofyalı Ali Çavuş Kanunnâmesi (1992), Hazl.: Midhat Sertoğlu, İstanbul: MÜ. FenEdebiyat Fakültesi Yayınları, No: 26

SüreyyA, M. (1996), Sicil-i Osmanî, Hazl.: Nuri Akbayar, İstanbul: Tarih Yurt Vakfı Yayınları, I, 28.

Şerafettin Han, (1971), Şerefnâme, Çev.: Mehmet Emin Bozaslan, İstanbul: Ant Yayınları.

Yılmazer, Z. (1990), Topçular Kâtibi Abdülkadir (Kadrî) Efendi Tarihi, Yayımlanmamış Doktora Tezi, iü. Sosyal Bilimler Enstitüsü, İstanbul.

Yılmazer, Z. (2006), "Murad IV”, DiA, XXXI, 175-183.

Zinkeisen, J. W. (2001), Osmanlı Imparatorluğu Tarihi, Çev.: Nilüfer Epçeli, İstanbul: Yeditepe Yayınları. 